\title{
SOURCES OF RETURN ON EQUITY IN ECONOMICALLY DIVERSIFIED AGRICULTURE OF THE EUROPEAN UNION COUNTRIES
}

\author{
JOANNA BEREŻNICKA
}

\begin{abstract}
The study analysed sources of return on equity in countries with strong and economically weak farms. The economic size used in FADN was used as the breakdown criterion. In the group of countries where farms reached a relatively small economic size, there were Bulgaria, Greece, Croatia (from 2013), Malta, Lithuania, Poland, Romania and Slovenia. Farms with a high standard value of production came from the Netherlands, Belgium, the Czech Republic, Denmark, Germany and Slovakia. The studies used panel methods, and the model with fixed effects was used to estimate model parameters. Factors that influenced the return on equity in the group of weaker countries included asset productivity, sales profitability (sales margin) and operating subsidies. In the group of countries with economically stronger farms, the return on equity rate was positively affected by the margin on sales and profitability of production measured by the ratio of total production to total costs and property debt. Which confirms that foreign capital can contribute to achieving positive effects from the perspective of the return on equity.
\end{abstract}

Keywords: return on equity, economically strong agriculture, economically weak agriculture.

JEL codes: D22, Q14, G32.

Dr Joanna Bereżnicka, Szkoła Główna Gospodarstwa Wiejskiego, Wydział Nauk Ekonomicznych, Katedra Finansów; ul. Nowoursynowska 166, 02-787 Warszawa (joanna_bereznicka@sggw.pl), 


\section{Introduction}

Agriculture is quite an important sector of the national economy, despite its small and decreasing share in the creation of GDP (Mrówczyńska-Kamińska, 2009), but at the same time the level of income in agriculture is lower in comparison with other sectors of the economy (Średzińska, 2017). This significance and role is confirmed by programmes addressed to agriculture. They are designed to help farmers achieve profitability, i.e. the ability to generate profit. According to Offermann and Nieberg (2000), profit is generally one of the most common and accepted measures of successful economic activity. Profitability measurement is made in various aspects, i.e. sales, assets or equity. It seems that each of them is important, but from the point of view of the owner, the return on equity is a key indicator and point of assessment of the rationale of the conducted business, including agricultural. Equity is an essential source of financing in most of the EU countries (exceptions: the Netherlands, Denmark) (see Kata, 2011). Similar conclusions were reached by Barry, Bierlen and Sotomayor (2000), indicating that farmers prefer own funds in the hierarchy of financing sources. And as Detre and Mishra (2012) state, the growing share of assets in relation to equity results, e.g. from the size of the farm. Agriculture is diversified in terms of the economic strength of its entities, which translates into differences in the range of return rates. The main source of profitability should be operational activity (mainly sales), but it also may be the result of using external sources of funding (subsidies). The question is whether in European countries with economically strong and weak agriculture, profitability will be created by the same sources, especially when the level of support for agriculture in developing countries is lower than in developed countries (development paradox) (see Poczta-Wajda 2017).

\section{Literature review}

The issue of profitability on Polish farms was discussed in the literature in relation to its various aspects: return on equity - Gołaś (2009), return on sales - Ryś-Jurek (2013), return on assets - Zawadzka and Szafraniec-Siluta (2015). However, this issue is also raised outside the agricultural sphere (Bednarski, 2002; Dudycz, 2001; Gołaś, 2008; Hawawini and Viallet, 2007). Despite the fact that the discussed indicators are clearly structured and do not cause interpretation problems, the possibilities of their broad description are limited, therefore, the view that they should be disaggregated, enabling a multidimensional and cause-and-effect analysis of various financial phenomena, including those related to profitability, appears in the literature. The study of profitability changes can be considered in relation to specific factors, e.g. total factor productivity (TFP) and the index measuring relative price changes. The TFP can be further broken down into measures of technical changes, changes in technical efficiency, or change in efficiency or effectiveness (O'Donnel, 2010). The most well-known and commonly used method indicating the factors of return on equity is the Du Pont Model (Bieniasz, Czerwińska-Kayzer and Gołaś, 2008; Gołaś, 2009). It shows a method of a pyramidal explanation of return on equity from the level of balance sheet and result data. 
As previously mentioned, the main source of income (profit) should be operating activity, but due to high price volatility in agriculture and biological nature of this activity, farmers often point to problems with obtaining income from production, which indicates some limitations in making decisions. However, according to Špicka, Boudný and Janotová (2009), payments partially or totally unrelated to the volume of production serve as a "financial cushion" which helps to increase income of farmers and helps them make decisions regarding their day-to-day operations and investment activities. The latter may be a source of income in the following years, because, as Bórawski and Brodziński (2006) believe, high values of the return on equity ratio indicate the profitability of investments in assets of the enterprise. Unfortunately, Bereżnicka's research (2015) showed that investments in Polish family farms did not bring an increase in income. The reason was directing funds to not necessarily the right areas as well as little interest in using loan (low income and risk aversion). As indicated by Folz (2004), the existence of restrictions on the credit market has a significant impact on the profitability of farms, although it does not affect the value of investments. Therefore, poor economic results are a direct cause of effective investment activities. In this context, it should be noted that endogenous factors, including production potential and economic size or agricultural type, are important determinants of the income situation (Średzińska, 2017), but it seems that also the way of management (conventional and organic farming). The problem of profitability of organic farms in developed and developing countries was studied by Nemes (2009). These studies indicated that, in developed countries, in addition to prices (which farmers do not have impact on), premiums influence the amount of income generated, while in developing countries the amount of premiums is lower, that is why the author suggests that farmers should reduce costs and improve productivity.

Other studies on the profitability of agriculture, using the empirical model estimated with the weighted least squares procedure, were conducted by Mishra, El-Osta and Steele (1999). The results indicated that the factors determining profitability were the manager's age, soil productivity, asset debt ratio and the relation of fixed and variable costs to production. On the other hand, Katchova and Enlow (2013), using the Du Pont Model, noticed that trading in assets had the greatest impact on return on equity. However, Kulawik (ed.) (2008) stated that the ROE may be affected by the following factors: operational efficiency, effective use of assets and leverage. Other studies indicated that support in the form of a single area payment did not affect the efficiency (Kulawik and Płonka, 2014). Boyd, Boland, Dhuyvetter and Barton (2007) studied the determinants of return on equity in local farms and cooperatives trading in cereal in the USA to identify financial variables which are the determinants of return on capital in them. The results of these studies confirmed that the estimated value of assets was not statistically significant. The lack of impact of net assets and leverage on ROE is confirmed by research carried out by Anarfi and Danquah (2017), whereas the profit margin and the size of an enterprise are important factors which have a positive impact on return on equity. Summing up, it should be concluded that research on profit- 
ability is carried out in the field of basic agricultural activity. The question arises whether other sources of profitability in agriculture are missing. Moreover, the factors mentioned by the researchers influence the profitability in various ways, which means that research in this area has not been exhausted yet and space for further exploration has been created.

\section{Objective and method}

The objective of the study was to identify profitability sources measured by the return on equity in agriculture of the EU countries, different in terms of the economic size of farms. The study formulates the thesis that in economically weaker agriculture the basic source of profitability are return on sales (sales margin) and subsidies to operations, while in stronger economies, except for return on sales, the ROE is affected by financing by debt (positive effect of the leverage), and non-returnable support does not have vital importance. Data used for the research comes from the Farm Accountancy Data Network (FADN), which allows us to collect data to assess the phenomena occurring in agriculture in the European Union (EU) countries. Data was collected from all 28 EU countries, which between 2009 and $2015^{1}$ reported on the situation of agriculture under the FADN. Preliminary analysis of data allowed concluding that the economic size (SE005 variable) of an average farm in individual countries was very diverse. This recognition resulted in the grouping of objects using the quartile method to create homogenous groups of countries in terms of standard output (SO), which was the basis for the construction of models. The first quartile (the smallest economic size) included countries such as: Bulgaria, Greece, Croatia, Malta, Lithuania, Poland, Romania, Slovenia (the volume of standard output was about EUR 33 thousand). In this paper, it is the group marked as Q1. However, the group of economically strongest (quartile 3, Q3) included the following countries: Belgium, the Czech Republic, Denmark, Germany, the Netherlands, Slovakia with the average SO was over EUR 190 thousand.

The return on equity calculated according to the following formula ${ }^{2}(1)$ was used to achieve the goals in the study:

$$
R O E=\frac{S E 420}{S E 501}
$$

SE420 - income from a family farm, SE501 - value of equity.

\footnotetext{
${ }^{1}$ In 2009, a new way of measuring the economic size of a farm was used in the FADN, which was standard output, before that the economic size was determined based on the standard surplus. Croatia, which joined the European Union in 2013, was also included in the research.

${ }^{2}$ While calculating the ROE, the relation of income from a family farm to equity was used. Due to the possibility of making a mistake of estimating payment for farmer's own work and work of the family for all the countries studied, the farm profit was not calculated.
} 
The starting point in the search for variables to diagnose factors affecting the ROE was the Du Pont Model, which not only measures profitability, but also examines the areas of the enterprise being its source. In addition, it is an excellent tool for quick review of the strengths and weaknesses of a company. The DuPont Model covers the following areas: profitability, operational efficiency and leverage (Kharatyan, Lopes and Nunes, 2017). Due to the fact that in the majority of the quoted studies the factor affecting the return on equity is return on sales (ROS), it was taken into consideration as the main factor. However, due to the fact that, apart from the basic activity (production and sales), agricultural income also includes subsidies (other operating activities), the ROS was given in two differently calculated ways, as ROS1 and ROS2 according to formulas (2) and (3).

$$
R O S 1=\frac{S E 420-S E 605}{S E 131-S E 260-S E 265-S E 256}
$$

and

$$
R O S 2=\frac{S E 420}{S E 131-S E 260-S E 265-S E 256}
$$

where:

SE605 - the amount of subsidies to operating activities,

SE131 - total production value,

SE260 - transfers to a household,

SE265 - internal consumption,

SE256 - other production,

other designations as above.

The aim of this solution was to check whether the sale of plant and livestock products guarantees income and what is the margin on the goods sold. In the author's opinion, the sale of agricultural products and services should be the basic source of wealth of a farmer, but also an entrepreneur conducting economic activity outside agriculture, because it is a confirmation of the rightness of the decision on business operations in a given area. The productivity of assets (production to assets) and the profitability of production (the total production to total costs relation) were used as a measure of operational efficiency, while the asset debt ratio was the variable in the area of financial activity.

Due to the fact that the cross-sectional and temporal data was analysed in the study, panel methods were used for the construction of models. These models describe a fixed group of objects for more than one period. Thanks to information about objects and their simultaneous characterisation in individual periods, panel data models allow reducing the measurement error resulting from the omission of important variables unobservable for these objects. These models take into account the impact of two types of factors (general and specific) on the analysed objects. 
There are two types of panel models: a model with fixed effects and a model with random effects (Korol and Szczuciński, 2012). Franc-Dąbrowska (2009) wrote about the possibility of using panel models in research on agricultural holdings. The paper uses a model with fixed effects (the GLS model), which assumes that individual effects are the same in subsequent periods. In this model, individual effects can be interpreted as non-random components. The general formula of the model is as follows (4):

$$
y_{i t}=x_{i t} \beta+u_{i}+\varepsilon_{i t}
$$

where:

$y$ - dependent variable,

$u_{i}$ - individual effect,

$\varepsilon_{i t}-$ pure random error (Kufel, 2007).

Individual effects determined are eliminated by averaging the model with respect to time (index t) and then the equation (4) takes the following form:

$$
\frac{1}{T} \sum_{t=1}^{T} y_{i t}=\frac{1}{T} \sum_{t=1}^{T} x_{i t} \beta+\frac{1}{T} \sum_{t=1}^{T} u_{i}+\frac{1}{T} \sum_{t=1}^{T} \varepsilon_{i t}
$$

The equivalent record of the equation (5) is as follows:

$$
\bar{y}_{i}=\bar{x}_{i} \beta+u_{i}+\bar{\varepsilon}_{i}
$$

It should be emphasised that this solution ignores the situation of strict exogeneity and the occurrence of variables whose values are constant over time for all panel units (Kufel, 2007).

The GRETL programme was used to calculate and construct the model. The panel was fully balanced in terms of countries included in Q3 and not fully balanced for countries included in Q1. In the latter case, this concerns data on Croatia from 2013 (before that, the country was not a member of the European Union). The dependent variable was the amount of return on equity according to formula (1). Some variables were subjected to finding a logarithm, this applies mainly to nominal values, this procedure allowed standardising the variables and obtaining their symmetrical distribution.

In addition, descriptive and comparative analysis was used in the work.

\section{Characteristics of the studied groups}

Conducted research concerned farms diversified in terms of production potential, therefore, Table 1 compares basic data characterising separated groups as regards equipment with basic production factors, i.e. land, labour and capital. 
Table 1

Basic statistics describing equipment with land, labour and capital in the analysed groups in the analysed period

\begin{tabular}{|c|c|c|c|c|c|c|c|c|c|c|c|c|c|c|}
\hline \multirow{3}{*}{$\begin{array}{l}\text { Specifica- } \\
\text { tion }\end{array}$} & \multicolumn{14}{|c|}{ Year } \\
\hline & \multicolumn{2}{|c|}{2009} & \multicolumn{2}{|c|}{2010} & \multicolumn{2}{|c|}{2011} & \multicolumn{2}{|c|}{2012} & \multicolumn{2}{|c|}{2013} & \multicolumn{2}{|c|}{2014} & \multicolumn{2}{|c|}{2015} \\
\hline & Q1 & Q3 & Q1 & Q3 & Q1 & Q3 & Q1 & Q3 & Q1 & Q3 & Q1 & Q3 & Q1 & Q3 \\
\hline \multicolumn{15}{|c|}{ Land (ha) } \\
\hline Average & 18.5 & 169 & 19.1 & 166 & 19.0 & 175 & 19.3 & 158 & 21.5 & 171 & 21.8 & 167 & 21.2 & 168 \\
\hline Minimum & 3.3 & 35.7 & 2.7 & 36.4 & 2.6 & 36.6 & 2.7 & 37.6 & 9.3 & 36.5 & 9.2 & 36.9 & 9.0 & 36.3 \\
\hline Maximum & 46.3 & 526 & 47.9 & 509 & 46.7 & 553 & 46.4 & 475 & 48.6 & 551 & 47.5 & 532 & 46.3 & 529 \\
\hline $\begin{array}{l}\text { Standard } \\
\text { deviation }\end{array}$ & 15.4 & 187 & 16.3 & 181 & 15.9 & 198 & 16.4 & 165 & 15.5 & 195 & 16.4 & 188 & 15.1 & 186 \\
\hline \multicolumn{15}{|c|}{ Labour (AWU) } \\
\hline Average & 1.73 & 5.02 & 1.70 & 4.78 & 1.62 & 4.98 & 1.60 & 4.42 & 1.62 & 4.75 & 1.60 & 4.46 & 1.55 & 4.79 \\
\hline Minimum & 1.28 & 1.81 & 1.24 & 1.71 & 1.18 & 1.69 & 1.16 & 1.66 & 1.08 & 1.76 & 1.10 & 1.71 & 1.07 & 1.73 \\
\hline Maximum & 2.66 & 14.5 & 2.58 & 13.3 & 2.48 & 14.7 & 2.49 & 12.1 & 2.41 & 13.9 & 2.42 & 12.4 & 2.35 & 12.4 \\
\hline $\begin{array}{l}\text { Standard } \\
\text { deviation }\end{array}$ & 0.44 & 4.98 & 0.44 & 4.53 & 0.43 & 5.05 & 0.45 & 4.04 & 0.45 & 4.73 & 0.46 & 4.14 & 0.45 & 4.15 \\
\hline \multicolumn{15}{|c|}{ Capital (EUR thousand) } \\
\hline Average & 115 & 1271 & 127 & 1310 & 126 & 1349 & 130 & 1332 & 120 & 1403 & 128 & 1367 & 129 & 1391 \\
\hline Minimum & 37 & 596 & 35 & 586 & 39 & 618 & 36 & 656 & 37 & 729 & 35 & 624 & 35 & 670 \\
\hline Maximum & 197 & 2726 & 201 & 2608 & 189 & 2544 & 198 & 2482 & 188 & 2530 & 213 & 2458 & 214 & 2490 \\
\hline $\begin{array}{l}\text { Standard } \\
\text { deviation }\end{array}$ & 62 & 885 & 59 & 876 & 51 & 809 & 55 & 854 & 52 & 837 & 57 & 832 & 59 & 828 \\
\hline
\end{tabular}

Source: own calculations on the basis of data for ec.europa.eu/agriculture/rica/database/database_en.cfm (access date: 15 March 2018).

While analysing data in Table 1 , it should be clearly stated that there were significant differences in the equipment with production factors in the studied groups of countries. The equipment of economically strong agriculture with basic production factors, land, was on average 8-9 times higher than in countries with economically weaker farms. On the other hand, the number of annual work units in the Q3 group was 2-3 times lower per 100 ha of utilised agricultural area (UAA). Of course, this is a consequence of technical equipment of labour at a much more advanced level, which was confirmed by the amount of capital available to farmers. In countries included in Q1, there was over 10 times less capital than in the compared Q3 group, or even 15 times in case of the poorest Romania.

In this comparison, Poland was below the average as regards equipment with land (about 18.4 ha in the entire examined period), labour inputs amounted to over 
9 annual work units (AWU), which is similar to other countries of the Q1 group. Equipment with capital, in spite of growth from around EUR 134 thousand in 2009 to EUR 169 thousand in the last analysed year, remained below the average in the Q1 group. However, it should be emphasised that in the analysed period the capital resources were slowly increasing in nominal terms. An important element affecting profitability is financial activity, especially the use of external sources of financing which may have a leverage effect (Dulieciec, 2011; Grzywacz, 2012). Table 2 compares data on the share of foreign capital in financing assets, because, according to Moballeghi and Moghaddam (2013), financial capital plays an important role from the point of view of profitability of small businesses.

Table 2

Indebtedness of assets in the studied groups (\%)

\begin{tabular}{|c|c|c|c|c|c|c|c|c|c|c|c|c|c|c|}
\hline \multirow{3}{*}{$\begin{array}{l}\text { Specifica- } \\
\text { tion }\end{array}$} & \multicolumn{14}{|c|}{ Year } \\
\hline & \multicolumn{2}{|c|}{2009} & \multicolumn{2}{|c|}{2010} & \multicolumn{2}{|c|}{2011} & \multicolumn{2}{|c|}{2012} & \multicolumn{2}{|c|}{2013} & \multicolumn{2}{|c|}{2014} & \multicolumn{2}{|c|}{2015} \\
\hline & Q1 & Q3 & Q1 & Q3 & Q1 & Q3 & Q1 & Q3 & Q1 & Q3 & Q1 & Q3 & Q1 & Q3 \\
\hline Average & 7.56 & 30.3 & 5.90 & 29.9 & 6.97 & 30.7 & 6.28 & 30.3 & 6.97 & 29.5 & 7.83 & 33.5 & 8.00 & 34.7 \\
\hline Minimum & 0.78 & 19.1 & 0.62 & 15.4 & 0.49 & 16.0 & 0.36 & 13.6 & 0.33 & 15.4 & 0.08 & 21.5 & 0.04 & 22.6 \\
\hline Maximum & 19.7 & 53.4 & 13.0 & 55.6 & 20.2 & 58.7 & 14.7 & 59.4 & 20.8 & 58.6 & 24.7 & 59.1 & 21.9 & 58.7 \\
\hline $\begin{array}{l}\text { Standard } \\
\text { deviation }\end{array}$ & 7.0 & 13.1 & 4.9 & 14.5 & 7.2 & 15.5 & 5.8 & 16.1 & 7.9 & 15.5 & 9.0 & 13.2 & 7.9 & 12.6 \\
\hline
\end{tabular}

Source: as for Table 1.

Data included in Table 2 again show significant differences between groups of countries in terms of financing by debt. In the group of countries with economically strong agriculture, on average, about $30 \%$ of foreign capital is used to finance resources. In the group of weaker countries, it is 4-5 times less. These disproportions were even more visible in the case of minimum sizes, where in the Q1 group the share of external financing (long-term and short-term) did not reach even $1 \%$ of the property value. It should be added that the financing structure was different in both analysed groups, i.e. in the $\mathrm{Q} 3$ group, long-term debt prevailed in relation to assets, and in the Q1 group, farmers used long- and short-term debt in financing assets to a similar extent. In Poland's situation, the debt of assets varied around 5-6\%, so it was not even the average level for this Q1 group. This indicates a very cautious approach of Polish farmers to the use of foreign sources of financing despite the fact that in recent years investment processes in Polish farms have accelerated, which resulted in increased indebtedness.

An important external (non-reimbursable and no-cost) source of financing of operating (agricultural) activities are subsidies, the essence of which is to support farmers in obtaining income from a family farm. Table 3 shows the share of subsidies to operating activities (variable SE605) to the production volume. 
Table 3

Share of subsidies to operating activities in the value of agricultural production (SE605/SE131) (\%)

\begin{tabular}{|c|c|c|c|c|c|c|c|c|c|c|c|c|c|c|}
\hline \multirow{3}{*}{$\begin{array}{l}\text { Specifica- } \\
\text { tion }\end{array}$} & \multicolumn{14}{|c|}{ Year } \\
\hline & \multicolumn{2}{|c|}{2009} & \multicolumn{2}{|c|}{2010} & \multicolumn{2}{|c|}{2011} & \multicolumn{2}{|c|}{2012} & \multicolumn{2}{|c|}{2013} & \multicolumn{2}{|c|}{2014} & \multicolumn{2}{|c|}{2015} \\
\hline & Q1 & Q3 & Q1 & Q3 & Q1 & Q3 & Q1 & Q3 & Q1 & Q3 & Q1 & Q3 & Q1 & Q3 \\
\hline Average & 24 & 22 & 22 & 18 & 19 & 15 & 19 & 15 & 24 & 15 & 23 & 15 & 22 & 15 \\
\hline Minimum & 11 & 5 & 11 & 5 & 9 & 5 & 8 & 5 & 16 & 4 & 13 & 3 & 8 & 4 \\
\hline Maximum & 33 & 47 & 32 & 40 & 29 & 27 & 29 & 28 & 33 & 28 & 30 & 27 & 27 & 28 \\
\hline $\begin{array}{l}\text { Standard } \\
\text { deviation }\end{array}$ & 8.0 & 15.6 & 8.0 & 13.3 & 7.0 & 8.9 & 7.0 & 9.5 & 6.0 & 10.4 & 5.0 & 9.6 & 6.0 & 9.8 \\
\hline
\end{tabular}

Source: as for Table 1.

In 2009, the average share of subsidies to operating activities in the group of countries with economically strong agriculture was close to that occurring in economically weak countries, and accounted for less than one quarter of the value of agricultural production. In the following years, these proportions increased to the disadvantage of the latter (although there was a downward trend in the share of subsidies). In the Q3 group, the average share was around 15\% starting from 2011, however, it should be noted that there were significant differences between countries - greater spread was noted in the group of countries with economically strong agriculture and in the first analysed year it amounted to $38 \mathrm{pp}$, decreasing to $24 \mathrm{pp}$ in 2014 and 2015. In the same period in the Q1 group it amounted to $22 \mathrm{pp}$, $17 \mathrm{pp}$ and $19 \mathrm{pp}$, respectively. It should be emphasised that in the last analysed year, the maximum share of subsidies to operating activities in both groups was similar, which may indicate a decrease in the value of production in countries from Q1 or increase in the support provided. The lowest amount of subsidies in relation to the value of production was noted in the Netherlands, which should not come as a surprise due to the high productivity in the agriculture of this country. One should also remember that there are no subsidies due to the specialisation of farms in some areas of production. The most unfavourable relation concerned agriculture of the Czech Republic and Slovakia, which was probably caused by the structure of farms in these countries, dominated by large-scale agricultural holdings with hired labour force (see Baer-Nawrocka, 2013).

In the Q1 group, relatively the lowest amount of subsidies was received by Romanian farmers, and the highest by Greeks and Slovenes. Poland received subsidies at a level higher than the average for the Q1 group, but there was a slow decrease from $24 \%$ in 2009 to $18 \%$ in 2015 . The reason for this was the decreasing amount of subsidies, with a slight increase in the value of production. This may indicate a slow tendency in the growth of productivity in Polish agriculture (probably as a result of investment activities). Both the volume of production and the value of subsidies affect the amount of income from a family farm. Table 4 presents figures on value added resulting from the basic activity of farms and agricultural income. 
Table 4

The level of net value added (excluding subsidies to operating activity SE415-SE605) and direct payments (EUR thousand)

\begin{tabular}{|c|c|c|c|c|c|c|c|c|c|c|c|c|c|c|}
\hline \multirow{2}{*}{$\begin{array}{l}\text { Specifica- } \\
\text { tion }\end{array}$} & \multicolumn{2}{|c|}{2009} & \multicolumn{2}{|c|}{2010} & \multicolumn{2}{|c|}{2011} & \multicolumn{2}{|c|}{2012} & \multicolumn{2}{|c|}{2013} & \multicolumn{2}{|c|}{2014} & \multicolumn{2}{|c|}{2015} \\
\hline & Q1 & Q3 & Q1 & Q3 & Q1 & Q3 & Q1 & Q3 & Q1 & Q3 & Q1 & Q3 & Q1 & Q3 \\
\hline \multicolumn{15}{|c|}{ Net value added (SE415-SE605) } \\
\hline $\mathrm{Av}$ & 4.1 & 10.6 & 5.8 & 44.4 & 6.4 & 61.2 & 6.7 & 70.3 & 4.6 & 72.2 & 4.8 & 62.6 & 4.7 & 54.2 \\
\hline Minimum & -0.8 & -133.6 & -1.2 & -73.4 & 0.5 & 10.2 & -1.5 & -4.6 & -2.3 & 9.4 & -1.8 & 22.2 & -1.5 & 4.9 \\
\hline $\operatorname{Max}$ & 8.5 & 85.9 & 9.7 & 125.4 & 11.4 & 107.3 & 12.4 & 133.9 & 9.1 & 136.7 & 12.1 & 117.9 & 9.6 & 123.2 \\
\hline Sta & 3.1 & 76 & 3.6 & 69 & 3.3 & 38.7 & 4.4 & 52.9 & 3.5 & 50.0 & 4.4 & 30.6 & 3.6 & 34.6 \\
\hline \multicolumn{15}{|c|}{ Payments to operating activities (SE605) } \\
\hline $\mathrm{Av}$ & 5.7 & 60.6 & 5.9 & 58.1 & 5.4 & 59.8 & 5.6 & 53.8 & 6.6 & 58.3 & 6.4 & 59.1 & 6.2 & 58.0 \\
\hline Minimum & 1.7 & 18.9 & 1.5 & 19.9 & 1.6 & 21.1 & 1.8 & 22.5 & 1.9 & 18.2 & 1.5 & 16.3 & 0.9 & 19.5 \\
\hline Maximum & 8.5 & 169.2 & 8.8 & 153.1 & 8.1 & 158.3 & 8.3 & 128.5 & 10.0 & 150.8 & 10.2 & 158.2 & 10.4 & 152.1 \\
\hline $\begin{array}{l}\text { Standard } \\
\text { deviation }\end{array}$ & 2.4 & 56.8 & 2.5 & 50.7 & 2.3 & 52.8 & 2.3 & 40.8 & 2.9 & 50.7 & 2.9 & 54.1 & 3.1 & 51.9 \\
\hline
\end{tabular}

Source: as for Table 1.

Figures compared in Table 4 clearly indicate that the average value of subsidies in the studied groups was higher than the value of net added production resulting only from carrying out main business. The exception was the period between 2011 and 2014, in which economies with economically stronger agriculture developed higher net value added compared to external financial support received. However, in the first years after the financial crisis (2009-2010), its unfavourable effects are noticeable in these economies. In 2015, subsidies are beginning to dominate over agricultural production again. The highest net value added and the lowest value of subsidies was achieved by Dutch farmers. The situation of Slovakia was different. Farmers in this country were basing mainly on subsidies to operating activities, while they achieved minimum values in terms of result from production. This means that prices obtained for agricultural products and services sold were lower than the purchase prices of production inputs and costs of external factors (employed labour costs were probably decisive). It should also be noted that the minimum value added in the group of economically weaker farms was negative in all years, which indicates too small scale of production which would be able to cover the costs of agricultural activity (this applies to Slovenia), while the highest values in this group occurred in Bulgaria. Poland achieved results slightly above the average for the group. This proves the decreasing role of basic activity of agriculture in relation to external financing. Therefore, agriculture is becoming a sector of the economy where profit is sourced from outside financial support, i.e. activities accompanying main operating activities. 
Table 5

The value of return on sales (ROS), equity (ROE) and assets (ROA), and in the analysed period and groups (\%)

\begin{tabular}{|c|c|c|c|c|c|c|c|c|c|c|c|c|c|c|}
\hline \multirow{2}{*}{$\begin{array}{l}\text { Specifica- } \\
\text { tion }\end{array}$} & \multicolumn{2}{|c|}{2009} & \multicolumn{2}{|c|}{2010} & \multicolumn{2}{|c|}{2011} & \multicolumn{2}{|c|}{2012} & \multicolumn{2}{|c|}{2013} & \multicolumn{2}{|c|}{2014} & \multicolumn{2}{|c|}{2015} \\
\hline & Q1 & Q3 & Q1 & Q3 & Q1 & Q3 & Q1 & Q3 & Q1 & Q3 & Q1 & Q3 & Q1 & Q3 \\
\hline $\begin{array}{l}\text { Average } \\
\text { ROS1 }\end{array}$ & 12 & -33 & 17 & -13 & 18 & -4 & 15 & -3 & 9 & -3 & 10 & -5 & 11 & -8 \\
\hline \multicolumn{15}{|c|}{ Return on sales (ROS2) } \\
\hline Average & 45 & -2 & 48 & 10 & 44 & 14 & 41 & 16 & 38 & 16 & 39 & 14 & 39 & 11 \\
\hline Minimum & 21 & -46 & 28 & -17 & 23 & 4 & 24 & -2 & 23 & -1 & 24 & 3 & 26 & -3 \\
\hline Maximum & 64 & 23 & 67 & 30 & 57 & 23 & 53 & 27 & 54 & 24 & 59 & 23 & 55 & 20 \\
\hline $\begin{array}{l}\text { Standard } \\
\text { deviation }\end{array}$ & 17 & 25 & 14 & 16 & 13 & 7.5 & 12 & 9.8 & 11 & 9.1 & 11 & 7.1 & 7.5 & 5.9 \\
\hline \multicolumn{15}{|c|}{ Return on equity (ROE) } \\
\hline Average & 9 & 0 & 10 & 4 & 10 & 6 & 10 & 6 & 9 & 6 & 9 & 6 & 9 & 4 \\
\hline Minimum & 4 & -15 & 4 & -6 & 4 & 2 & 3 & -1 & 3 & -1 & 2 & 2 & 2 & -1 \\
\hline Maximum & 15 & 10 & 16 & 16 & 16 & 12 & 17 & 14 & 15 & 11 & 15 & 13 & 14 & 9 \\
\hline $\begin{array}{l}\text { Standard } \\
\text { deviation }\end{array}$ & 4.7 & 8.4 & 5.2 & 7.3 & 4.9 & 3.8 & 5.1 & 4.8 & 5.0 & 3.8 & 4.9 & 4.2 & 4.7 & 2.9 \\
\hline \multicolumn{15}{|c|}{ Return on assets (ROA) } \\
\hline Average & 8.3 & -0.1 & 8.4 & 2.7 & 9 & 3.9 & 9 & 4.3 & 8.4 & 4.0 & 7.8 & 4.4 & 7.8 & 3.6 \\
\hline Minimum & 3.7 & -12.0 & 3.5 & -5.2 & 3.7 & 1.2 & 2.7 & -0.8 & 2.6 & -0.5 & 2.1 & 1.0 & 2.2 & 0.5 \\
\hline Maximum & 14.1 & 7.2 & 15.1 & 11.2 & 14.9 & 8.4 & 14.5 & 9.1 & 14.8 & 8.0 & 14.9 & 9.1 & 11.2 & 6.4 \\
\hline $\begin{array}{l}\text { Standard } \\
\text { deviation }\end{array}$ & 4.3 & 6.4 & 4.8 & 5.4 & 4.5 & 2.9 & 4.5 & 3.6 & 4.4 & 3.1 & 4.3 & 3.2 & 3.8 & 2.2 \\
\hline
\end{tabular}

Source: as for Table 1.

Data in Table 5 clearly indicates that subsidies to operating activities contributed to the increase in rates of return on sales for both economically weaker and strong agriculture. At the same time, a more positive impact is visible in the Q3 group, which may be a bit of a surprise (however, this confirms income deprivation in agriculture). Without subsidies, agriculture in the countries of this group was unable to achieve income and showed losses. In addition, even external support in this group did not allow everyone to achieve a positive rate of return on sales. The problem concerns Slovakia and the Czech Republic. It is worth noting that after including subsidies the return on sales was at a lower level than in the group of countries with economically weaker agriculture. Figures in Table 5 also show that agriculture from countries included in $\mathrm{Q} 3$ reacted to the financial crisis, which was affecting these economies practically until 2010 to a greater extent. 
On the other hand, in all years agriculture in countries included in the Q1 group was able to achieve a positive margin on sales even in the absence of subsidies. This was probably the effect of much worse equipment with production factors, which generated fixed costs. This mainly concerns costs of depreciation and external factors. In all analysed years, return on equity in the Q1 group remained at a similar level of $9-10 \%$, and $4-6 \%$ in the Q3 group. This means that the money involved in agriculture brought a relatively lower rate of return on equity than in economically weaker economies. This is surprising especially that in these cases financing from external sources was greater. However, probably the use of foreign capital in these countries was at a relatively low level (a large share of equity in the financing of assets) which adversely affected the return on own funds. The highest rates of return on equity were achieved by farmers in Belgium and the Czech Republic (in the Q1 group, farmers from Bulgaria and Lithuania). In this comparison, Poland was below the average with a result of around 5\% (in the last two years of the analysis, 6-7\% before that) of the rate of return on equity. Loss on equity employed was incurred by farmers from Slovakia. The Netherlands, which showed the highest value of the net value added, but profitability of around 4\%, is also a little surprise. This result was a consequence of the costs of external factors, i.e. rent, interest, or payment for hired labour. This observation is somewhat contradictory to the statement of Machek (2014), who suggested that total productivity of factors, measured with monetary aggregates, such as added value, will always be positively correlated with the financial profitability ratios, if the calculations are based on the same data. In addition, it should be noted that in all years and studied groups, the rate of return on equity was slightly higher compared to return on assets, whereas the return on sales (regardless of whether subsidies are taken into account or not) showed the highest values except for the first years after the crisis (2009-2011) in the absence of subsidies.

\section{Sources of profitability - model solutions}

Table 6 summarises explanatory variables which affected the dependent variable - the rate of return on equity - in the group of countries with agriculture having its economic size expressed in SO above 190 units, while Table 7 presents the model developed for the group in which the average economic size was around 33 units (the Q1 group). Due to different units of measure between the dependent and independent variables, a logarithm was found for explanatory variables. 
Table 6

Estimation established effects, robust standard errors (robust HAC), dependent variable (Y): $R O E$ - model for the Q3 group

\begin{tabular}{lccccc}
\hline \multicolumn{1}{c}{ Variables } & Rate & Standard error & t-distribution & p-value & Significance \\
\hline const. & 0.580915 & 0.237868 & 2.442 & 0.0877 & $*$ \\
$\begin{array}{l}\text { Production to costs } \\
\text { (SE132) }\end{array}$ & 0.200723 & 0.0689821 & 2.910 & 0.0530 & $*$ \\
ROS1 & 0.132907 & 0.0133406 & 9.963 & 0.0003 & $* * *$ \\
Debt of assets & 0.116133 & 0.0199729 & 5.815 & 0.0040 & $* * *$ \\
Log_equity & -0.0554809 & 0.0208965 & -2.655 & 0.0696 & $*$ \\
\hline
\end{tabular}

\begin{tabular}{lrlr}
\hline Arithmetic mean of dependent variable & 0.047286 & Standard deviation of dependent variable & 0.054155 \\
The sum of squared residuals & 0.002183 & Standard error of residuals & 0.008260 \\
R squared coefficient of determination & 0.981843 & Adjusted R squared & 0.976736 \\
F 9,32$)$ & 192.2635 & p-value for the F-test & $2.92 \mathrm{e}-25$ \\
Log likelihood & 147.5606 & Akaike info. criterion & -275.1211 \\
Schwarz criterion & -257.7444 & Hannan-Quinn information criterion & -268.7519 \\
Autocorrelation of the residuals - tho1 & 0.094860 & Durbin-Watson statistic & 1.390668 \\
\hline
\end{tabular}

Test for normality of residual distribution - Null hypothesis: random component has normal distribution. Test statistic: Chi-squared $(2)=11.1717$ with $\mathrm{p}=0.00374902$

Source: own calculations using the GRETL programme.

Table 7

Estimation established effects, robust standard errors (robust HAC), dependent variable (Y): $R O E$ - model for the Q1 group

\begin{tabular}{lrrrrc}
\hline \multicolumn{1}{c}{ Variables } & \multicolumn{1}{c}{ Rate } & Standard error & t-distribution & p-value & Significance \\
\hline const. & 0.234167 & 0.209483 & -0.3417 & 0.2707 & \\
Log_subsidies & 0.0477647 & 0.0933188 & 4.615 & 0.036 & $* * *$ \\
Log_equity & -0.0300244 & 0.0958673 & -2.854 & 0.0290 & $* *$ \\
Return on assets & 0.250584 & 0.0356151 & 7.036 & 0.0004 & $* * *$ \\
ROS1 & 0.216528 & 0.0405897 & 5.335 & 0.018 & $* * *$ \\
\hline
\end{tabular}

\begin{tabular}{lrlr}
\hline Arithmetic mean of dependent variable & 0.092293 & Standard deviation of dependent variable & 0.046448 \\
The sum of squared residuals & 0.001724 & Standard error of residuals & 0.06735 \\
R squared coefficient of determination & 0.983356 & Adjusted R squared & 0.96293 \\
F $(9,38)$ & 86.17294 & p-value for the F-test & $5.81 \mathrm{e}-23$ \\
Log likelihood & 181.7237 & Akaike information criterion & -341.4473 \\
Schwarz criterion & -320.6373 & Hannan-Quinn information criterion & -333.5520 \\
Autocorrelation of the residuals - tho1 & 0.344738 & Durbin-Watson statistic & 1.080196 \\
\hline
\end{tabular}

Test for normality of residual distribution - Null hypothesis: random component has normal distribution. Test statistic: Chi-squared(2) $=9.27569$ with $\mathrm{p}=0.00967853$.

Source: as for Table 6. 
Variables describing the return on equity in the group of economically stronger farms refer to operating activities - return on sales (sales margin) and profitability of agricultural production (relation of production to costs), as well as financial activity - reflected in the asset debt ratio. The above-mentioned factors are the stimulants of return on equity. This means that in agriculture of countries characterised by large economic size of farms, in addition to operating activities, financial activities (leverage) are also the source of return on equity. The results of this study are consistent with the assessment of Kulawik (2008). The return on equity log had an adverse effect on the size of ROE, which may be obvious considering the ROE calculation formula. However, on the other hand, it confirms the increase in the value of equity by farms, and thus also the increase in the wealth of farmers running them. This may indicate too high values of this capital in farms in relation to the income earned. Therefore, there is still space in these farms for increasing debt, which will allow increasing the efficiency of equity capital. It should be added that the factors (explanatory variables) in the model explain the return on capital to a very large extent.

In the second model (regarding the Q1 group), the source of profitability was only operating activity carried out in the form of return on assets and return on sales, however, direct subsidies to operating activity were also of importance, although lesser than the aforementioned ones. This means that farmers in this group of farms make better use of their assets. Moreover, profitability is affected by the sales margin (0.216 and 0.11 for Q3) to a greater extent (than in the Q3 group). Factors which should be treated as a destimulant include - of course - the equity $\log$. Variables included in the model indicate that in this group of farms there was no positive impact of debt on the return on equity. This situation is not surprising because the debt ratios in this group were at a very low level.

In conclusion, it should be noted that even though the factors influencing the return on equity in groups were different, they were mainly related to operating activities (basic and other), although the role of financial activity cannot be neglected either.

\section{Summary}

The analysis was aimed at identifying sources of profitability in countries with economically stronger and weaker farms. The research allows stating that there is a gap between the analysed farms in virtually all areas, i.e. equipment with production factors, achieved economic results or even the amount of received subsidies. The farms classified as Q1 had surface area or capital several times lower and received almost 10 times lower subsidies, which of course was a consequence of being equipped with the basic agricultural production factor. Nevertheless, the share of subsidies in the production volume was more favourable on weaker farms. The research also allowed us to state that the achievement of return on sales in farms from Q3 in the absence of subsidies to operating activities could be at risk. This situation did not occur in the Q1 group. The probable reason for this is a significant level of fixed costs (depreciation) and costs of external factors. 
As for the verification of the hypothesis proposed in the paper, it was confirmed. The research proved that the main source of profitability in weaker farms was operating activity related to return on assets and profitability of production, as well as subsidies to operating activities. On the other hand, for economically stronger farms, the source of profitability was, apart from operating activities (sales), also financial activities, which indicates that farmers in the countries of the Q3 group used foreign capital in a right way. Subsidies to operating activities did not play a significant role in shaping the return on equity. 


\section{References}

Anarfi, D., Danquah, K.A.B. (2017). Determinants of Return on Equity in the Czech Agric and Forest Industry. Journal of Innovative Research in Business \& Econnnomics, vol. 1, issue 01 , pp. 43-49.

Baer-Nawrocka, A. (2013). Wpływ Wspólnej Polityki Rolnej na efekty dochodowe w rolnictwie nowych krajów członkowskich Unii Europejskiej. Polityki Europejskie, Finanse i Marketing, no. 9(58), pp. 34-44.

Barry, P., Bierlen, R.W., Sotomayor, N.L. (2000). Financial Structure of Farm Business under Imperfect Capital Markets. American Journal of Agricultural Economics, vol. 82, pp. 920-933.

Bednarski, L. (2002). Analiza finansowa przedsiębiorstwa. Warszawa: PWE.

Bereżnicka, J. (2015) Koncentracja kapitału a efektywność finansowa gospodarstw rodzinnych. Zagadnienia Ekonomiki Rolnej, no. 3(344), pp. 88-100.

Bieniasz, A., Czerwińska-Kayzer, D., Gołaś, Z. (2008). Wykorzystanie modelu Du Ponta do określenia czynników kształtujących rentowność przedsiębiorstw przemysłu przetwórczego. Zeszyty Naukowe SGGW, Ekonomika i Organizacja Gospodarki Żywnościowej, no. 64, pp. 53-64.

Boyd, S., Boland, M., Dhuyvetter, K., Barton, D. (2007). Determinants of Return on Equity in US Local Farm Supply and Grain Marketing Cooperatives. Journal of Agricultural and Applied Economics, no.39(1), pp. 201-210.

Bórawski, P., Brodziński, Z. (2006). Analiza finansowa sektora małych i średnich przedsiębiorstw na przykładzie województwa warmińsko-mazurskiego. Acta Scientiarum Polonorum Oeconomia, no. 5(2), pp. 17-24.

Detre, D., Mishra, A. (2012). Drivers of agricultural profitability in the USA: An application of the Du Pont expansion method. Agricultural Finance Review, vol. 72, no. 3, pp. 325-340.

Dudycz, T. (2001). Pomiar efektywności przedsiębiorstwa w stosunku do zainwestowanego kapitału. Rachunkowość, no. 4, pp. 242-249.

Duliniec, A. (2011). Finansowanie przedsiębiorstwa. Warszawa: PWE.

Foltz, J.D. (2004). Credit market access and profitability in Tunisian agriculture. Agricultural Economics, vol, 30, issue 3, pp. 229-240.

Franc-Dąbrowska, J. (2009). Praktyczne zastosowanie wybranych modeli panelowych do oceny sytuacji finansowej w przedsiębiorstwach rolniczych, Zeszyty Naukowe SGGW, Ekonomika i Organizacja Gospodarki Żywnościowej, no. 76, pp. 31-40.

Gołaś, Z. (2009). Czynniki determinujące rentowność kapitału własnego w rolnictwie. Journal of Agribusiness and Rural Development, no. 1(11), pp. 75-91.

Grzywacz, J. (2012). Kapitał w przedsiębiorstwie i jego struktura. Warszawa: Wydawnictwo SGH. Hawawini, G., Viallet, C. (2007). Finanse menadżerskie. Warszawa: PWE.

Kata, R. (2011). Endogeniczne i instytucjonalne czynniki kształtujące powiązania finansowe gospodarstw rolnych z bankami. Prace Naukowe Wydziału Ekonomii Uniwersytetu Rzeszowskiego, seria Monografie i Opracowania, no. 14.

Katchova, A.L., Enlow, S.J (2013). Financial performance of publicly-traded agribusiness. Agricultural Finance Review, no. 73(1), pp. 58-73.

Kharatyan, D., Lopes, J.C., Nunes, A. (2017). Determinants of Return on Equity: Evidence from Nasdaq100. Retrieved from: https://bibiotecadigital.ipb.pt/bitstream/10198/14213/1/ Determinants_ROE_Nasdaq100.pdf (access date: 23.07.2018). 
Korol, J., Szczuciński, P. (2012). Ekonometryczne modelowanie zróżnicowania związków w sektorze małych i średnich przedsiębiorstw w przestrzeni regionalnej. Metody ilościowe $w$ Ekonomii, Studia i Prace Wydziału Nauk Ekonomicznych i Zarzadzania, no. 26, pp. 209-224.

Kufel, T. (2007). Ekonometria. Rozwiąywanie problemów z wykorzystaniem programu GRETL. Warszawa: Wyd. Naukowe PWN.

Kulawik, J. (red.). (2008). Analiza efektywności ekonomicznej i finansowej przedsiębiorstw rolnych powstałych na bazie majątku WRSP. Warszawa: IERiGŻ-PIB.

Kulawik, J., Płonka, R. (2014). Subsydia i efektywność ekonomiczno-finansowa a typ produkcyjny gospodarstw osób fizycznych. Zagadnienia Ekonomiki Rolnej, no. 3(340), pp. 25-43.

Machek, O. (2014). The Relationship Between Financial Performance and Total Factor Productivity: Evidence from the Czech Agricultural Sector. International Journal of Social Sciences and Humanity Studies, vol 6, no. 2, pp. 57-67.

Mishra, A.K., El-Osta, H.S., Steele, Ch.J. (1999). Factors Affecting the Profitability of Limited Resource and Other Small Farms. Agricultural Finance Review, vol. 59, pp. 77-99.

Moballeghi, M., Moghaddam, G.F. (2013). Firm size, beta and Financial Leverage. Stock Exchange in Iran. SCMS Journal of Indian Management, 40-47.

Mrówczyńska-Kamińska, A. (2008). Znaczenie rolnictwa w gospodarce narodowej w Polsce, analiza makroekonomiczna i regionalna. Zeszyty Naukowe SGGW, Problemy Rolnictwa Światowego, no. 5(20), pp. 96-107.

Nemes, N. (2009). Comparative Analysis of Organic and Non-Organic Farming Systems: A Critical Assessment Of Farm Profitability, Food and Agriculture Organization of the United Nations, Rome.

O'Donnell,C.(2010). Measuring and decomposing agricultural productivity and profitability change. Australian Journal of Agricultural and Resource Economics, vol. 54, no. 4, s. 527-560.

Offermann, F., Nieberg, H. (2000). Economic Performance of Organic Farms in Europe. Organic Farming in Europe. Economics and Policy, vol. 5.

Poczta-Wajda, A. (2017). Polityka wspierania rolnictwa a problem deprywacji dochodowej rolników w krajach o różnym poziomie rozwoju. Warszawa: PWN.

Ryś-Jurek, R. (2013). Rentowność sprzedaży w sektorze gospodarstw rolnych w Polsce na tle krajów Unii Europejskiej. Wieś i Rolnictwo, no. 4, pp. 161-172.

Špicka, J., Boudný, J., Janotová, B. (2009). The Role of Subsidies in Managing the Operating Risk of Agricultural Enterprises. Agricultural Economics - Zemedelska ekonomika, vol. 55, no. 4, pp. 169-179.

Średzińska, J. (2017). Zróżnicowanie poziomu dochodów rolników w gospodarstwach o różnych typach rolniczych w krajach Unii Europejskiej. Finanse, Rynki Finansowe, Ubezpieczenia, no. 5(89), cz. 1, pp. 145-155.

Xaba,B.G.,Masuku, M.B.(2013).Factors Affecting the Productivity and Profitability of Vegetables Production in Swaziland. Journal of Agricultural Studies, vol. 1, no. 2, pp. 37-52.

Zawadzka, D., Szafraniec-Siluta, E. (2015). Rentowność aktywów przedsiębiorstw Rolniczych w Polsce - ocena porównawcza. Zeszyty Naukowe Stowarzyszenie Ekonomistów Rolnictwa i Agrobiznesu, vol. XVII, issue. 6, pp. 339-345.

ec.europa.eu/agriculture/rica/database/database_en.cfm (access date: 15.03.2018). 


\title{
ŹRÓDŁA RENTOWNOŚCI KAPITAŁU WŁASNEGO \\ W ZRÓŻNICOWANYM EKONOMICZNIE ROLNICTWIE KRAJÓW UNII EUROPEJSKIEJ
}

\begin{abstract}
Abstrakt
W pracy przeanalizowano źródła rentowności kapitału własnego $w$ krajach o silnych oraz słabych ekonomicznie gospodarstwach rolnych. Jako kryterium podziału zastosowano wielkość ekonomiczna stosowana w FADN. W grupie krajów, w których gospodarstwa osiagały relatywnie nieduża wielkość ekonomiczna, znalazły się Bułgaria, Grecja, Chorwacja (od 2013 r.), Malta, Litwa, Polska, Rumunia i Słowenia. Gospodarstwa o dużej wartości standardowej produkcji pochodziły z Holandii, Belgii, Czech, Danii, Niemiec i Słowacji. W badaniach posłużono się metodami panelowymi, a do estymacji parametrów modelu wykorzystano model z efektami stałymi. Wśród czynników, które wpływały na rentowność kapitału własnego, w grupie krajów ze słabszymi gospodarstwami znalazły się produktywność aktywów, rentowność sprzedaży (marża na sprzedaży) oraz dopłaty do działalności operacyjnej. W grupie państw z silniejszymi ekonomicznie gospodarstwami na stope zwrotu z kapitału własnego pozytywny wpływ wywierały: marża na sprzedaży oraz opłacalność produkcji mierzona relacją produkcji ogółem do kosztów ogółem oraz zadłużenie majątku. Co potwierdza, że kapitat obcy może przyczynić się do osiagniecia pozytywnych efektów z perspektywy stopy zwrotu z kapitału własnego.
\end{abstract}

Słowa kluczowe: rentowność kapitału własnego, rolnictwo silne ekonomicznie, rolnictwo słabe ekonomicznie.

Accepted for print: 5.09.2018.

Unless stated otherwise all the materials on the website are available under the Creative Commons Attribution 4.0 International license.

Some rights reserved to the Institute of Agricultural and Food Economics - National Research Institute.

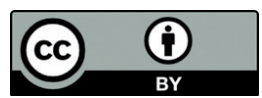

